\title{
Grzegorz Erlebach
}

\section{Ochrona wolności nupturientów w kanonicznym porządku prawnym : zarys problematyki}

Prawo Kanoniczne : kwartalnik prawno-historyczny 52/3-4, 195-214

2009

Artykuł został opracowany do udostępnienia w internecie przez Muzeum Historii Polski w ramach prac podejmowanych na rzecz zapewnienia otwartego, powszechnego i trwałego dostępu do polskiego dorobku naukowego i kulturalnego. Artykuł jest umieszczony w kolekcji cyfrowej bazhum.muzhp.pl, gromadzącej zawartość polskich czasopism humanistycznych i społecznych.

Tekst jest udostępniony do wykorzystania w ramach dozwolonego użytku. 


\section{OCHRONA WOLNOŚCI NUPTURIENTÓW W KANONICZNYM PORZADKU PRAWNYM. ZARYS PROBLEMATYKI}

Treść: Wstęp. - 1. Zasada wolności nupturientów. -2. Przymus i bojaźń. -3. Brak wolności wewnętrznej. - 4. Podstępne wprowadzenie w błąd. - Zakończenie.

\section{Wstęp}

Wolność i małżeństwo należą do wartości podstawowych, mimo iż innego zupełnie porządku. Przedmiotem niniejszej refleksji jest ochrona zakresu wspólnego tych dwóch wartości, a dokładniej wolności nupturientów, czyli tej wolności, która jest niezbędna w momencie zawierania małżeństwa. To «temat rzeka», nawet jeśli jest ograniczony do ochrony tejże wolności w kanonicznym porządku prawnym. Konieczne jest zresztą dodatkowe zawężenie tego tematu do samego tylko prawa materialnego, choć pewne uwagi dotyczące praktyki sądowej okażą się niezbędne. Bez zasadniczego uszczerbku dla całości problematyki można wyjść z założenia, że dochodzenie stwierdzenia nieważności zawarcia małżeństwa stanowi w gruncie rzeczy aspekt techniczno-pochodny. W centrum uwagi należy natomiast postawić pytanie czy i na ile kanoniczny porządek prawny przewiduje ochronę wolności w zawieraniu małżeństwa. Ramy czasowe tej konferencji pozwalają jedynie na pobieżne nakreślenie zasygnalizowanej problematyki.

\section{Zasada wolności nupturientów}

Kanon 219 deklaruje ogólną zasadę wolności od przymusu w wyborze stanu życia: «wszyscy wierni maja prawo być wolni od jakiegokolwiek przymusu w wyborze stanu życia». Ta enuncjacja ma swoje 
«źródło w naturalnym prawie osoby ludzkiej» ${ }^{1}$, prawie do samostanowienia. Jest ono związane z samą istotą osoby ludzkiej jako bytu indywidualnego, podmiotowego, zdolnego do wchodzenia w relacje parytetyczne $\mathrm{z}$ innymi osobami ludzkimi.

Te naturalne, niejako, korzenie zasady wolności od przymusu w wyborze stanu życia, kierują uwagę w pierwszym rzędzie na filozoficzne, a dokładniej antropologiczne, rozumienie wolności. Na tej płaszczyźnie rozróżnia się przede wszystkim między wolnością jako brakiem przymusu wywieranego ze strony innych, ogólniej brakiem uwarunkowań zewnętrznych, a zdolnością do autodeterminacji. W pierwszym przypadku mamy do czynienia z wolnością «od», w drugim zaś $\mathrm{z}$ wolnością «do». ${ }^{2}$ Zasada wolności od przymusu w wyborze stanu życia zapisuje się więc w dziedzinie szeroko pojętej wolności «od», ale sama w sobie nie jest jeszcze wystarczająca, będąc wolnością «negatywną», mimo iż ogromnej wartości, pozytywnej oczywiście. Jednostka jest antropologicznie w pełni wolna jedynie wtedy, gdy jest również zdolna do korzystania z wolności «do», mianowicie gdy jest zdolna do autoderminacji, do podejmowania decyzji angażujących istotne wymiary jej życia, a często $\mathrm{i}$ innych osób, gdy jest zdolna do autodeterminacji ze względu na określone wartości.

Gdy idzie o aspekt autodeterminacji za względu na określone wartości, wszyscy są zgodni co do tego, że «wartość jest wartościowa», że jest godna realizacji, ale nie wszyscy są zgodni, co do identyfikacji poszczególnych wartości. Tu jawi się potrzeba odwołania do wolności w sensie teologicznym, mianowicie do wolności człowieka w odniesieniu do Boga. Wolność zakłada możliwość wyboru między dobrem a złem (KKK, art. 1732), ale jest też w człowieku «siłą wzrastania i dojrzewania w prawdzie i dobru», osiągając «swoją doskonałość, gdy jest ukierunkowana na Boga, który jest naszym szczęściem» (KKK, art. 1731). Nie chodzi więc o jakąkolwiek wartość, być może jedną z wielu, ale o Kogoś, kto się jawi jako najwyższe dobro, o dobro osobowe, o Boga miłującego. Nie jest to miłość statyczna, oświecająca tylko, ale miłość pociągająca, stanowiąca imperatyw dla ludzkiego działania. W tym świetle nie każda filo-

${ }^{1}$ J. K r u k o w s k i, komentarz do kan. 219, w: Komentarz do Kodeksu Prawa Kanonicznego, t. II/1, J. Krukowski (red.), Poznań 2005, s. 36.

${ }^{2}$ Por. G. B a s t i, Filosofia dell'uomo, Bologna 1995, s. 265-267. 
zoficznie pojęta autodeterminacja jest wyrazem wolności; jest nim tylko ta autodeterminacja, która realizuje wartości ukierunkowane ku wartości najwyższej, ku Bogu samemu. Odpowiedź pozytywna na dar i powołanie Boże stanowi autodeterminację autentycznie wolną i wyzwalająca, bo poszerzającą zakres wewnętrznej wolności.

W kontekście naszego tematu należy podkreślić, że teologiczne rozumienie wolności nakazuje nam wyjść poza rozumienie indywidualistyczne małżeństwa i osadzić je w kontekście relacji do Boga, uzdalniającego do ofiarnej miłości i powołującego do małżeństwa. Małżeństwo jest więc nie tylko godziwe - co musiał rewindykować św. Augustyn w dyskusji z manichejczykami, formułując słynne «bona»: bonum fidei, sacramenti et prolis - ale dla większości ludzi jest również zadaniem ze strony Stwórcy, wzywającym do tej właśnie autodeterminacji. Małżeństwo, jako takie, jest więc niewątpliwie dobrem. Na płaszczyźnie prawa odpowiada mu uprawnienie podstawowe, formułowane jako ius connubii, któremu daje wyraz kan. 1058: «małżeństwo mogą zawrzeć wszyscy, którym prawo tego nie zabrania».

Ochrona prawna małżeństwa, w pierwszym rzędzie zasada wolności nupturientów w wyborze stanu życia małżeńskiego, ma więc korzenie głęboko teologiczne. Nic więc dziwnego, że małżeństwo było przedmiotem uwagi wielu interwencji Urzędu Nauczycielskiego Kościoła. I to nie tylko małżeństwo sakramentalne, które jest przedmiotem specyficznym nauczania kościelnego, ale małżeństwo jako takie. W tym kontekście godne uwagi jest to, że tak Magisterium Kościoła jak i zwyczajne nauczanie pasterzy Kościoła jest ukierunkowane na ukazywanie głębokiego wymiaru małżeństwa, jego celu i potencjalności. Gdy idzie o wolność nupturientów, Magisterium ma na uwadze przede wszystkim wychowywanie do wolności, tak by nupturienci byli zdolni do odpowiedzialnej autodeterminacji w zawieraniu małżeństwa i następnie byli w stanie, korzystając również z pomocy naturalnych i środków łaski, postępować na drodze miłości ofiarnej w małżeństwie i w rodzinie.

Ten zasadniczy zamysł Magisterium Kościoła w dziedzinie nauczania o małżeństwie i idąca za tym praca duszpasterska, zwłaszcza na polu katechizacji i bezpośredniego przygotowania do małżeństwa, przyczyniają się pośrednio do ochrony wolności nupturientów. W kanonicznym porządku prawnym interesuje nas jednak aspekt 
bardziej specyficzny: czy i na ile Ustawodawca chroni wolność nupturientów przy pomocy środków mających skutek prawa?

Wracając do kan. 219, fundamentalnego w tej materii, należy zauważyć, że Ustawodawca nie proklamuje tam wprost prawa do wolnego wyboru stanu życia, a jedynie prawo do wolności od jakiegokolwiek przymusu w wyborze stanu życia. Powszechnie przyjmuje się szeroką interpretację wolności od przymusu, rozumiejąc pod słowami quaevis coactio (kan. 219) jakikolwiek przymus: fizyczny, psychologiczny, moralny, w tym również przymus wewnętrzny (coactio ab intrinseco $)^{3}$. Komentatorzy koncentrują swoją uwagę na różnych formach przymusu pozytywnego, rozumianego jako określonego rodzaju presja, wywarta celem spowodowania podjęcia decyzji, ze strony osoby przymuszonej, co do zawarcia małżeństwa w ogóle lub z określoną osobą. Nie można jednak pomijać przymusu negatywnego, majaccego postać tak czy inaczej postawionego zakazu zawarcia małżeństwa, czy to w ogólności, czy z kimś należącym do określonej kategorii osób, czy wreszcie z konkretną osobą. Wydaje się, że i ta forma naruszenia wolności wchodzi w zakres postanowienia kan. 219, mimo iż nie pociąga za sobą dalszych konsekwencji prawnych. Co więcej, jeśli osoba, znajdująca się pod presją przymusu negatywnego, mimo wszystko zawrze małżeństwo, będące przedmiotem kontestacji, to tym samym ta osoba zdaje się wykazywać posiadanie nieprzeciętnej zdolności do autodeterminacji. Nie można więc przypuszczać, by owo faktyczne naruszenie wolności zewnętrznej mogło powodować konsekwencje tak negatywne, by wymagały interwencji ze strony Ustawodawcy.

Wracając więc do proklamacji prawa do wolności ${ }^{4}$ od jakiegokolwiek przymusu w wyborze stanu życia (kan. 219), ów przymus nie może być rozumiany inaczej w kontekście prawa (prawa wolności od przymusu) jak tylko przymus zewnętrzny. Co więcej, niemalże wbrew dzisiejszej tendencji do szerokiej interpretacji kan. 219, zdaje się, że przedmiotem dyspozycji tego kanonu moga być tylko te formy przymusu zewnętrznego, które spowodowane są przez osoby ludzkie, niezależnie od tego czy w sposób zamie-

${ }^{3}$ Por. A. S t a n k i e w i c z, Il metus ab intrinseco e l'immunità dalla coazione nella scelta dello status personale (can. 219), w: AA.Vv., La «vis vel metus» nel consenso matrimoniale canonico (can. 1103), Studi giuridici - 71, Città del Vaticano 2006, s. 272.

${ }^{4}$ Por. również H. F r a n c e s c h i, Il diritto alla libera scelta del proprio coniuge quale diritto fondamentale della persona, w: „Ius Ecclesiae” 8 (1996), s. 154-170. 
rzony czy nie. Trudno bowiem, by nupturient mógł dysponować uprawnieniem w odniesieniu do czynników zewnętrznych naturalnych lub nieosobowych. To zmusza do refleksji nad koniecznością wyraźnego odróżnienia przedmiotu dyspozycji prawnej kan. 219 (prawo do wolności od przymusu zewnętrznego, tak pozytywnego jak i negatywnego) od racji tegoż kanonu (zasada wolności w wyborze stanu życia).

To ostatnie rozróżnienie jest bardzo istotne gdy idzie o środki prawne, które należy podjaćć w ramach niniejszego tematu. Okazuje się bowiem, że gdy idzie o środki przewidziane w kanonicznym porzadku prawnym przeciw naruszeniu kan. 219 w relacji do zawarcia małżeństwa, to przysługuje jedynie ochrona prawna w granicach przewidzianych w kann. $125 \S 1$ i 1103 . Jeśli natomiast zostanie postawione pytanie o ochronę prawną wolności nupturientów w zawieraniu małżeństwa, to dochodzi również ochrona wolności wewnętrznej i ochrona pośrednia w ramach obowiązywalności kan. 1098, na ile racją ostatniego kanonu jest ochrona wolności kontrahentów.

\section{Przymus i bojaźń}

Najbardziej ewidentną formą naruszenia wolności nupturienta jest wywieranie zewnętrznego przymusu.

Jeśli przymus zostaje wywarty z użyciem siły, której nie sposób się w żaden sposób oprzeć (określanej nieraz w doktrynie jako vis physica), zgoda jest oczywiście nieważna: potwierdza to kan. $125, \S$ 1; co więcej, tak wyrażona zgoda uchodzi za nie dokonaną. Należy jednak mieć na uwadze, że Ustawodawca deklaruje brak zaistnienia takiego aktu prawnego w sytuacji, gdy siła zewnętrzna była przyczyną sprawczą samego tylko zewnętrznego wyrażenia zgody małżeńskiej, a więc gdy istnieje bezpośredni związek przyczynowości sprawczej między wywartą siłą a manifestacją zgody. W takiej sytuacji, nie ma wątpliwości co do braku zaistnienia zgody, ze względu na brak woli kontrahenta. W praktyce, tak skrajne przypadki są jednak niezwykle rzadkie.

Łatwiej może się natomiast zdarzyć, że przymus wywiera skutek za pośrednictwem bojaźni wywołanej u jednego z kontrahentów. W ten sposób wola osoby przymuszonej nie zostaje wykluczona, jest natomiast mniej lub bardziej ograniczona przez nacisk zewnętrzny i po części zdeterminowana do zawarcia małżeństwa z powodu 
wywołanej bojaźni. Mówiąc dalej o przymusie, ograniczę się do takiego właśnie rozumienia, określanego najczęściej jako vis et metus, co sygnalizuje współwystąpienie obu aspektów: określonego przymusu i wywołanej przezeń bojaźni w osobie przymuszonej. Inne określenie, często używane w przeszłości, to vis conditionalis: w ten sposób był uwypuklany aspekt przymusu skutkującego dokonaniem określonego aktu prawnego, do którego inaczej by nie doszło.

Pod wpływem prawa rzymskiego początkowo była przyjmowana w Kościele zasada nieważności aktów prawnych dokonanych pod wpływem przymusu. Prawo dekretałów wyraźnie to potwierdza 5 . Późniejsza jednak refleksja filozoficzno-teologiczna doprowadziła do sformułowania zasady przeciwnej, mianowicie zasady ważności aktów prawnych dokonanych pod wpływem przymusu wywołującego bojaźń; oparto się o przesłankę, że sama bojaźń nie wyklucza istnienia woli a powoduje jedynie involuntarium secundum quid. W tym kontekście powtarzano często adagium: coacta voluntas sed semper voluntas! Po linii tego zrewidowanego domniemania ${ }^{6}$ jawi się pierwsza część dzisiejszego kan. 125, § 2. Gdy idzie natomiast o tego rodzaju przymus wywarty na nupturientów, w całej tradycji kanonistycznej przyjmowano nieważność zgody, o ile został wywarty przymus kwalifikowany. Zasadniczym kryterium praktycznym oceny przymusu był «vir constans», tzn. kryterium zewnętrzne, według którego przymus wywołałby bojaźń nawet u «męża stałego». Według Kodeksu z 1917 r. nieważność małżeństwa miała miejsce, jeśli zostało zawarte «ob vim vel metum gravem ab extrinseco et iniuste incussum, a quo ut quis se liberet, eligere cogatur matrimonium» (kan. 1087, § 1). A więc były wymagane cztery elementy: ciężkość, charakter zewnętrzny przymusu, jego niesprawiedliwość i brak innej możliwości, poza zawarciem małżeństwa, by uwolnić się od bojaźni.

Racja prawna tej nieważności była nieraz upatrywana w sankcji wymierzonej przeciw niesprawiedliwości przymusu. W każdym bądź razie, w koncepcji kan. 1087, § 1, KPK 1917 widać wyraźnie, troskę o zrównoważone określenie parametrów, między przymusem wywartym z zewnątrz przez określoną osobę i odpowiednio wielką bojaź-

${ }^{5}$ Zob. «quae metu et vi fiunt de iure debent in irritum revocari» (X. 1, 40, 2) i «quae vi metusque causa fiunt carere debent robore firmitatis» (X. 1, 40, 4).

${ }^{6} \mathrm{Nie}$ stanowi to jednak absolutnej nowości; por. starorzymskie powiedzenie «etsi coactus, tamen volui» (D. 4, 2, 21, 5). 
nią spowodowaną w ten sposób w ofierze przymusu. Na płaszczyźnie doktryny prawa kanonicznego zwłaszcza tzw. świecka szkoła włoska poświęciła sporo uwagi różnym szczegółowym kwestiom w tej materii, opowiadając się na ogół za stosunkowo wąską interpretacją normy kodeksowej. Inna natomiast droga poszło orzecznictwo rotalne, które stosunkowo szybko skonsolidowało swoje szyki i skupiło uwagę przede wszystkim na bojaźni jako skutku przymusu (uwzględniając głównie kryterium subiektywne oceny ciężkości), odrzucając wymóg niesprawiedliwości przymusu i stając na stanowisku, że dla nieważności małżeństwa nie jest konieczny przymus wywarty intencjonalnie.? Sam zresztą wymóg przymusu wywartego «ab extrinseco» był interpretowany stosunkowo szeroko. Taka postawa orzecznictwa stała się główną przyczyną dla której, jeszcze przed Soborem Watykańskim II, rację kan. 1087 KPK 1917 zaczęto upatrywać w ochronie wolności nupturientów przed przymusem zewnętrznym. Późniejsze tendencje rozumienia konsensu małżeńskiego na bazie przesłanek antropologicznych doskonale harmonizowały z tą wypracowaną już jurysprudencją rotalną. Nic więc dziwnego, że tej właśnie interpretacji odpowiada zrewidowany w obecnym Kodeksie zapis kan. 1103: «nieważne jest małżeństwo zawarte pod przymusem i pod wpływem ciężkiej bojaźni z zewnątrz, choćby nieumyślnie wywołanej, od której, ażeby się uwolnić, zmuszony jest ktoś wybrać małżeństwo» ${ }^{8}$. Ustawodawca nie odstąpił więc w kan. 1103 od wymogu przymusu zewnętrznego, jako przyczyny bojaźni, uwypuklił jednak sytuację ofiary przymusu, uzależniając sankcję nieważności jedynie od efektu przymusu, mianowicie od ciężkości bojaźni i braku innej możliwości uniknięcia zła grożącego w razie nie podporządkowania się osobie wywierającej przymus.

Racja kan. 1103 wydaje się być ewidentna: jest nią ochrona wolności nupturientów przed przymusem zewnętrznym. Godne jest natomiast uwagi zestawienie tej normy z zapisem kan. 219. Okazuje

${ }^{7}$ Por. L. G h i s o n i, La vis vel metus, w: AA.Vv., La giurisprudenza della Rota Romana sul consenso matrimoniale (1908-2008), Studi giuridici - 83, Città del Vaticano 2009, s. 259-279.

${ }^{8}$ Wyrażenie «ob vim vel metum» trudno jednoznacznie przetłumaczyć na język polski. Wydaje się jednak, że właściwsze jest użycie spójnika «i» aniżeli «lub»; pierwszy jest uzasadniony treściowo, historycznie i nie sprzeciwia mu się znaczenie tekstowe; drugi natomiast, tzn. «lub», oddaje tylko jedno z możliwych znaczeń językowych, mimo że pierwszorzędne, to jednak łatwo mogące wprowadzać w błąd, niemal sugerujące, jakoby te dwa elementy (przymus, bojaźń) były alternatywne. 
się, że o ile w kan. 219, który stanowi bezpośrednią ochronę m.in. nupturientów, jest mowa o prawie do wolności od jakiegokolwiek przymusu, o tyle pośrednia ochrona prawna w formie sankcji nieważności zgody małżeńskiej, przewidziana w kan. 1103, jest znacznie węższa, bo wchodząca w grę jedynie w przypadku bojaźni ciężkiej i od której nie można się inaczej uwolnić jak przez zawarcie niechcianego małżeństwa.

Najciekawsza jest jednak kwestia źródła normy unieważniającej, o której traktuje kan. 1103. Można postawić sobie pytanie, czy pochodzi ona z prawa naturalnego czy z prawa pozytywnego ludzkiego? Jak wiadomo, za każda z tych opcji można przytoczyć określone argumenty. W przeszłości za prawem naturalnym, jako uzasadniającym nieważność małżeństwa zawartego pod przymusem, opowiedziało się wielu kanonistów i przemawia za tym praktyka nie udzielania sanatio in radice $\mathrm{w}$ przypadku przymusu ${ }^{9}$. Za obowiązywalnością tej sankcji na mocy samego tylko prawa pozytywnego stanęli inni sławni kanoniści, jak np. Gasparri, który uzasadniał to tym, że jak pod przymusem można ważnie zawrzeć inne akty prawne, tak samo można by ważnie zawrzeć małżeństwo, gdyby nie interwencja Kościoła dla ochrony osoby zmuszonej do małżeństwa ${ }^{10}$. Nie bez znaczenia jest też argument, że trudno przypuszczać, by szczegółowe ustalenia kodeksowe przymusu unieważniającego wynikały z prawa naturalnego; raczej wskazywałyby one na charakter prawa ludzkiego stanowionego. Tej trudności nie rozstrzyga rozwiązanie pośrednie, w myśl którego nieważność małżeństwa zawartego pod wpływem przymusu jest zakorzeniona w prawie naturalnym, natomiast szczegółowa determinacja tej nieważności jest wynikiem interwencji Ustawodawcy kościelnego; w ten sposób kwestia ta zostałaby jedynie przesunięta na płaszczyznę wątpliwości dotyczącej tego, czy interwencja najwyższego Ustawodawcy miałaby tu charakter deklaratywny czy konstytutywny.

W tym kontekście, dużego znaczenia nabrała odpowiedź Papieskiej Komisji ds. interpretacji autentycznej Kodeksu Prawa Kanonicznego z dnia 23 kwietnia 1987, w myśl której kan. 1103 może być stosowany

${ }^{9}$ Zob. G. C a b e $\mathrm{r} 1$ e $\mathrm{t} \mathrm{t} \mathrm{i}$, I requisiti del metus invalidante il consenso coniugale, w: Diritto matrimoniale canonico, vol. II: Il conseno, Studi giuridici - 61, P. A. Bonnet - C. Gullo (red.), Città del Vaticano 2003, s. 588-589.

${ }^{10} \mathrm{P}$. G a s p a $\mathrm{r}$ r i, Tractatus canonicus de matrimonio, vol. II, Typis Polyglottis Vaticanis, $1932^{9}$, s. 53 , n. 841. 
w odniesieniu do małżeństw akatolików ${ }^{11}$. Kanoniści niemal jednym chórem wyciągnęli stąd wniosek, że ta odpowiedź zakłada, iż nieważność, o której w kan. 1103, pochodzi z prawa naturalnego. Brak przekonania do takiego rozumienia wyraził jednak Urbano Navarrete, przytaczając w swoim komentarzu do powyższej deklaracji racje tak formalne (np. brak kompetencji wspomnianej Komisji do wydawania deklaracji autentycznych określających granice prawa naturalnego) jak i materialne ${ }^{12}$. Jeszcze dzisiaj kard. Navarrete uważa, że twierdzenie, iż przepis kan. 1103 pokrywa się z wymiarem substancjalnym prawa naturalnego jest ryzykowne, i stąd, według niego, wspomniana tu deklaracja z 1987 r. nie jest łatwo interpretowalna ${ }^{13}$. Ta kwestia domaga się jednak jednoznacznej odpowiedzi, ze względu na potrzebę pewności co do zakresu sankcji nieważności małżeństwa zawartego pod przymusem.

Wydaje mi się, że obydwie pozycje zawierają źdźbło prawdy, ale zarazem żadna $z$ nich nie jest $w$ pełni przekonywująca. Teza przemawiająca za sankcją nieważności z prawa naturalnego zdaje się przypisywać temu prawu treści, które trudno jest racjonalnie uzasadnić jako regulowane prawem naturalnym, nie mówiąc o trudności w ustaleniu granic obowiązywalności prawa naturalnego, a przy tym brak jednoznacznej wypowiedzi Magisterium kościelnego w tej materii $^{14}$. Odmawianie sanowania in radice małżeństw zawartych pod przymusem może być po prostu wyrazem wątpliwości co do możliwości takiej sanacji w danym przypadku ${ }^{15}$. Z kolei obstawanie przy argumentacji, że szczegółowe ustalenia kodeksowe w materii przymusu w konsensie małżeńskim są bardziej wyrazem techniki legislacyjnej niż prawa naturalnego, nie jest do końca słuszne; z jednej strony nic nie wskazuje na to, by Ustawodawca traktował zgodę wyrażoną pod

${ }^{11}$ AAS 79 (1987), s. 1132.

${ }^{12}$ „Periodica” 77 (1988), s. 497-510.

${ }^{13} \mathrm{U}$. N a v a $\mathrm{r} \mathrm{r}$ e $\mathrm{t}$ e, $L a$ «vis et metus», w: AA.Vv., $L a$ «vis vel metus» nel consenso matrimoniale canonico (can. 1103), Studi giuridici - 71, Città del Vaticano 2006, s. 31 int. 37.

${ }^{14}$ Znany jest, oczywiście, energiczny sprzeciw Soboru Trydenckiego wobec przymuszania do małżeństwa (sess. XXIV, Decr. De reformatione matrimonii, cap. IX), nie była to jednak deklaracja prawa Bożego naturalnego ani tym bardziej prawa boskiego pozytywnego.

${ }^{15}$ Pomijając fakt odmiennej dziś systematyki, w ten sposób Gasparri uzasadniał brak dyspensowania w materii przymusu (P. G a s p a $\mathrm{r} r \mathrm{i}$, Tractatus canonicus de matrimonio, cyt., s. 54, n. 843). 
przymusem jako konsens naturalnie skuteczny i go unieważniał przez lex irritans; $\mathrm{z}$ drugiej natomiast strony parametry legislacyjne moga być traktowane jako historycznie uwarunkowany wysiłek ustalenia granic obowiązywalności prawa naturalnego w tej materii. Co więcej, nie tyle deklaracje, ile praktyka Roty, odbiegajaca w niemałym stopniu od tekstualnego sformułowania kan. 1087, § 1, KPK 1917, wyraźnie rewindykowana w obecności Papieża ${ }^{16}$, nie jest wynikiem insubordynacji Roty, ile raczej przekonania, że zadaniem sądu kościelnego jest stwierdzenie nieważności małżeństwa, jeśli jest ona udowodniona i - milcząco - wynika z prawa naturalnego, nawet jeśli prawo pozytywne kościelne na to w pewnych wypadkach de facto nie pozwalało.

Tak czy inaczej, rozwiązanie tej kwestii polega chyba nie na bezwarunkowym przyjęciu za słuszną jednej lub drugiej klasycznej odpowiedzi, lecz na odwołaniu się do kategorii nieważności ex natura rei. Krótko mówiąc, ową «res» stanowi konsens małżeński. Do jego ważności nie wystarcza jednak wyrażenie jakiejkolwiek woli, lecz potrzebna jest wola, która osiągnęła minimalnie konieczny stopień autodeterminacji. W analogii do zasady, że nie wystarcza jakiekolwiek używanie rozumu, ale jest potrzebne rozeznanie krytyczne proporcjonalne do małżeństwa (discretio iudicii matrimonio proportionata), tak również i w tej materii nie wystarcza jakakolwiek wola, lecz wola proporcjonalnie konieczna, pamiętając przy tym, że przedmiotem zgody jest nie co innego, jak daleko idąca wspólnota życia (consortium totius vitae, communitas vitae et amoris coniugalis). Istnieje ścisły związek między wolą wyrażoną w konsensie a wolnością zewnętrzną, jako że wolność od przymusu jest warunkiem koniecznym, choć samym w sobie niewystarczajacym, by dana osoba mogła podjać decyzję zawarcia małżeństwa i faktycznie je zawarła. Wolność od przymusu jest przesłanką konieczną do autodeterminacji do małżeństwa, i to do małżeństwa z określoną osobą, jako że bezdyskusyjnie przyj-

${ }^{16}$ W czasie audiencji udzielonej Rocie 16 października 1922 r. z okazji inauguracji roku sądowego, ówczesny dziekan Giovanni Prior, podjął wprost, w swoim przemówieniu skierowanym do Papieża, najważniejsze punkty krytyki podniesionej przeciwko Rocie. Wśród nich znalazł się również zarzut stwierdzania, ze zwiększona łatwością, nieważności małżeństwa z tytułu vis et metus. Odpowiadając nań, dziekan Prior stwierdził, że nie chodzi tu o nic innego, jak tylko o kontynuację tradycyjnej postawy Kościoła, broniącej wolności, która winna być zagwarantowana tym, którzy maja zawrzeć małżeństwo nierozerwalne, i to właśnie dlatego, że nierozerwalne (AAS 14 [1922], s. 562). 
muje się, iż małżeństwo jest zawierane nie inaczej jak intuitu perso$n a e, \mathrm{z}$ racji tej a nie innej osoby.

Z takim rozumieniem koniecznej wolności substancjalnej od przymusu zewnętrznego, harmonizuje również orzecznictwo rotalne, które w analizie poszczególnych spraw stara się ustalić, czy ktoś zawarł małżeństwo ex metu albo tylko cum metu. W ostatnim przypadku, jeśli wprawdzie miało miejsce ograniczenie wolności przez przymus zewnętrzny, ale stanowiło to tylko faktor towarzyszący zasadniczo autonomicznie podjętej decyzji o zawarciu małżeństwa, nieważność nie jest stwierdzana i określa się taki przymus i bojaźń jako lekkie. Inaczej jest, jeśli decyzja o zawarciu małżeństwa została podjęta na skutek przymusu; mówi się wtedy - choć niezbyt precyzyjnie - o przymusie jako przyczynie sprawczej zawarcia małżeństwa. Brak wtedy koniecznej, ze względu na przedmiot zgody małżeńskiej, autodeterminacji. W takiej sytuacji zawarcia małżeństwa ex metu lub $o b$ metum (por. kan. 1103) uznaje się bojaźń jako ciężką, i stwierdza się nieważność małżeństwa o ile zachodziła faktycznie sytuacja konieczności zawarcia małżeństwa ze względu na grożące znaczne zło i brak było innej możliwości uniknięcia tego zła. Według tego sposobu rozumienia skutków prawnych przymusu, z natury konsensu małżeńskiego wynika jego nieważność, jeśli przymus zewnętrzny uniemożliwia wystarczającą autodeterminację do zawarcia małżeństwa. Na ile to zachodzi w danym przypadku, na tyle można stwierdzić nieważność małżeństwa zawartego pod przymusem poza Kościołem katolickim. Pozostaje oczywiście subtelna kwestia, czy kan. 1103 nie przewiduje szerszego marginesu ochrony prawnej przed przymusem zewnętrznym aniżeli sama tylko natura rei. Osobiście wydaje mi się, że nic nie wskazuje na taką wolę ze strony Ustawodawcy. Jeśli w poszczególnych przypadkach sędziowie kościelni dokonali interpretacji poszerzającej kan. 1103, należy to traktować raczej jako nadużycie prawa.

Tak więc, niezależnie od trudności interpretacyjnych i kwestii otwartych, można bez wątpienia przyjąć, że «kan. 1103 stanowi wyjątkowo wymowny przejaw chęci zagwarantowania przez prawodawce nupturientom wolności kwalifikowanej» ${ }^{17}$.

${ }^{17}$ W. G ó r a 1 s k i, Kanoniczna zgoda matżeńska, Gdańsk 1991, s. 213. 


\section{Brak wolności wewnętrznej}

Ochrona wolności nupturientów w kanonicznym porządku prawnym nie ogranicza się bynajmniej do samej tylko dziedziny przymusu zewnętrznego. Komplementarnym, niejako, aspektem jest ochrona wolności wewnętrznej nupturientów. Chodzi o te przypadki, w których występuje brak wystarczającej wolności w zawarciu małżeństwa, spowodowany zasadniczo przez czynniki patologiczne, dotyczące samego kontrahenta. Nie wyklucza się tu jednak możliwości współudziału pewnego nacisku psychicznego spowodowanego przez osoby trzecie (nie stanowiącego przymusu kwalifikowanego w myśl kan. 1103) lub przymusu sytuacyjnego (np. z racji niechcianej ciąży przedmałżeńskiej). W sytuacji zasadniczej normalności psychicznej i przy minimalnej dojrzałości emocjonalnej nie zakłada się, by jakiekolwiek elementy nacisku osobowego lub sytuacyjnego były w stanie naruszyć w sposób istotny sferę wolności wewnętrznej: w takich wypadkach decyzja o zawarciu małżeństwa stanowi raczej autodeterminację dokonaną na skutek rozeznania krytycznego swojej sytuacji. To domniemanie może zostać jednak uchylone w przypadku niektórych zaburzeń psychicznych (typowym przykładem może być osobowość zależna), lub poważnej niedojrzałości emocjonalnej, jeśli sfera wolności osobistej w odniesieniu do jawiącego się na horyzoncie wewnętrznym małżeństwa jest istotowo zawężona. W takiej sytuacji brak wystarczającej wolności wewnętrznej może skutkować na różnych płaszczyznach intrapsychicznych, zwłaszcza ograniczeniem zdolności oceny krytycznej lub zdeterminowaniem woli ad unum, tzn. do zawarcia małżeństwa, bez efektywnej możliwości dokonania wyboru (między zawarciem a nie zawarciem konkretnego małżeństwa). Osobnym czynnikiem, który dodatkowo może wpływać tak na funkcje intelektualne jak zwłaszcza wolitywne podmiotu, jest sfera uczuć, jeśli dana osoba nie jest w stanie wystarczająco im się oprzećc ${ }^{18}$. W literaturze kanonistycznej podnoszono również swego czasu kwestię możliwości istotnego wpływu podświadomości, ograniczającej faktycznie wolność wewnętrzną, ale zdaje się, że dialog na płaszczyźnie inter-

${ }^{18}$ Obszernie, w nurcie promującym ochronę wolności wewnętrznej, omawia te aspekty: E. T u r n a t u r i, Libertà e consenso matrimoniale, w: Matrimonium et ius. Studi in onore del Prof. Avv. Sebastiano Villeggiante, J. E. Villa Avila - C. Gnazi (red.), Studi giuridici - 69, Città del Vaticano 2006, s. 121-143. 
dyscyplinarnej z psychologią i psychiatrią ${ }^{19}$ doprowadził do poważnego zrewidowania tej kwestii w kierunku zasady uznawania istotnego zakresu wolności wewnętrznej, mimo istnienia takich czy innych uwarunkowań.

Brak wystarczającej wolności wewnętrznej nie powoduje jednak bezpośrednio nieważności zgody małżeńskiej; ma to miejsce jedynie wtedy, gdy ograniczenie wolności wewnętrznej skutkuje poważnym brakiem rozeznania oceniającego co do istotnych obowiązków małżeńskich (kan. 1095, n. 2), albo wręcz pozbawia stronę wystarczającego używania rozumu, co można założyć teoretycznie, ale trudno przypuszczać, by tego rodzaju sytuacja mogła faktycznie zaistniećc ${ }^{20}$. W praktyce mówi się więc jedynie o możliwości niezdolności, o której traktuje kan. 1095, n. 2.

Te aspekty wolności wewnętrznej były od dawna brane pod uwagę w orzecznictwie rotalnym ${ }^{21}$ mimo braku jakiejkolwiek wyraźnej dyspozycji prawnej: w czasie obowiązywalności KPK 1917 wychodzono z ogólnej zasady kan. 1081 § 1, w myśl której «matrimonium facit partium consensus inter personas iure habiles legitime manifestatus». ${ }^{22}$ Nie przyjmowano jednak braku wolności wewnętrznej jako autonomicznego tytułu nieważności. Z chwilą gdy na płaszczyźnie niektórych trybunałów lokalnych zaczęto zawiązywać nieraz spór

${ }^{19}$ Por. np. G. Z u a n a z z i, La capacità intellettiva e volitiva in rapporto al matrimonio canonico: aspetti psicologici e psichiatrici, w: AA.Vv., L'incapacità di intendere e di volere nel diritto matrimoniale canonico (can. 1095 nn. 1-2), Studi giuridici - 52, Città del Vaticano 2000, s. 304-307.

${ }^{20}$ Brano również pod uwagę możliwość niezdolności do podjęcia istotnych obowiązków małżeńskich, zostało to jednak de facto zaniechane. Teoretyczne rozważania nie prowadzą tu do wartościowych wniosków. Gdyby w szczególnym przypadku określona anomalia prowadziła do niezdolności podjęcia jakiegoś istotnego obowiązku małżeńskiego z racji ograniczonej wolności wewnętrznej, rzecz sprowadzałaby się raczej do kwestii faktycznej.

${ }^{21}$ Wyrok coram Anné z 26 stycznia 1971 stwierdza, że «Iurisprudentia N. S. T. saepissime iam denotavit ad validum consensum requiri libertatem internam» (RRDec., vol. LXIII, s. 67, n. 2). Por. też wyroki coram Lefebvre z 29 lipca 1972, RRDec., vol. LXIV, s. 514, n. 6; coram Stankiewicz z dnia 31 maja 1979, RRDec., vol. LXXI, s. 311-314, nn. 7-8; coram Serrano z dnia 29 października 1987, RRDec., s. 573-589.

${ }^{22}$ Swoistym echem ówczesnego orzecznictwa rotalnego są dzisiejsze pozycje doktrynalne, które usiłują argumentować za autonomicznym tytułem braku wolności wewnętrznej, nawiązując wprost do kan. 1057 (por. np. J. J. G a r c í a F a íl d e, La libertà psicologica e il matrimonio, w: AA.Vv., L'incapacità di intendere e di volere nel diritto matrimoniale canonico (can. 1095 nn. 1-2), Studi giuridici - 52, Città del Vaticano 2000, s. 44-45). 
wprost ob defectum libertatis internae, powstał problem. Gdy niektóre z tych spraw wpłynęly do Roty, ten sposób postępowania nie spotkał się z aprobatą. Czasem Ponensi sprzeciwiali się wyraźnie tytułowi «braku wolności wewnętrznej» ${ }^{23}$ lub sprowadzali go do tytułu braku rozeznania krytycznego ${ }^{24}$ lub wreszcie zawiązywali spór «ob defectum internae libertatis seu defectum discretionis iudicii $»^{25}$. Do dziś dominujący trend $\mathrm{w}$ orzecznictwie rotalnym przemawia przeciw autonomii tytułu nieważności «ob defectum libertatis internae» ${ }^{26}$.

Nie ulega wątpliwości, że istotne ograniczenie wolności wewnętrznej przy zawieraniu małżeństwa może być przyczyną nieważności zgody małżeńskiej, zwłaszcza jeśli zostanie uniemożliwiona zdolność do autodeterminacji w zawarciu małżeństwa. Konieczne jest tu jednak wyraźne odróżnienie aspektów substancjalnych (dotyczących figur nieważności zgody małżeńskiej), aspektów systematyki doktrynalnej (takiego czy innego zaszeregowania określonych defektów lub wad zgody) i praktyki sądowej (w tym, co dotyczy tytułów nieważności). Sporo jest jeszcze do zrobienia dla uzyskania wystarczającej jasności w tej dziedzinie. Nie ulega jednak wątpliwości, że tak na płaszczyźnie doktrynalnej jak i w orzecznictwie kościelnym poświęca się sporo uwagi problematyce wolności wewnętrznej w kontekście zgody małżeńskiej, mimo pewnej fluktuacji tak pojęciowej jak i, zda się, aplikacyjnej, co zresztą nie powinno dziwić, jako że problematyka ta, $\mathrm{z}$ natury swojej interdyscyplinarna, pojawiła się stosunkowo niedawno, a w konkretnych sprawach, nawet przy jasnych zasadach teoretycznych, trudno nieraz właściwie ocenić skutki ograniczonej wolności wewnętrznej dla ważności zgody małżeńskiej.

${ }^{23}$ Por. coram Bruno, wyrok z dnia 22 lipca 1988, RRDec., vol. LXXX, s. 483, n. 7.

${ }^{24}$ Zob. np. coram Turnaturi, wyrok z dnia 16 listopada 2000, S. Ioannis Portoricen., A. $111 / 00$, nn. 4-6.

Kontrowersje istniały również na płaszczyźnie lokalnej, jak to wynika z dekretu coram Boccafola z dnia 9 czerwca 2005: trybunał pierwszej instancji zawiązał spór «ob defectum libertatis internae», zaś trybunał lokalny apelacyjny «ob defectum discretionis iudicii» (Limana, B. 58/05, n. 3).

${ }^{25}$ Np. coram Funghini, wyrok z dnia 21 października 1987, RRDec., vol. LXXIX, s. 555 , n. 1 .

${ }^{26} \mathrm{~W}$ ostatnich latach również w samej Rocie przyjęto, tamquam in prima instantia, tytuł braku wolności wewnętrznej (por. coram Monier, dekr. z dnia 4 czerwca 2001, Bononien., B. 75/01; wyrok afirmatywny, wydany w tej sprawie, został ratyfikowany dekretem coram Defilippi z dnia 2 czerwca 2005, B. 54/05). Nie ulega jednak wątpliwości, że jak na razie tego typu decyzje stanowią orzecznictwo mniejszościowe. 


\section{Podstępne wprowadzenie w błąd}

Bezpośrednie naruszenie wolności wewnętrznej, czy to wywołanej przez przymus zewnętrzny czy też przez inne faktory powodujące brak wolności wewnętrznej, stanowi najbardziej ewidentną postać naruszenia wolności nupturientów w zawieraniu małżeństwa. Dla pełni obrazu należy jednak podjąć również pośrednie naruszenie wolności w postaci podstępnego wprowadzenia w błąd, a dokładniej rzecz biorąc związaną z tym ochronę wolności w kanonicznym porządku prawnym.

W pierwszym rzędzie należy zauważyć, że problematyka pośredniego zawężenia obszaru wolności jest znacznie szersza niż podstępne wprowadzenie w błąd: dotyczy bowiem tak ignorancji jak i każdej postaci błędu. W myśl tradycyjnej zasady nil volitum quin praecognitum, nie sposób zdecydować się na coś, czego się nie zna, albo, mówiąc pozytywnie, osoba może dokonać autodeterminacji na tyle, na ile zna przedmiot decyzji, która ma zostać podjęta. Całkowity brak poznania lub obraz po części fałszywy, prowadzą pośrednio do niemożliwości realnej autodeterminacji, tzn. dają jedynie ograniczoną możliwość autodeterminacji, co stoi w ścisłym związku z przynajmniej zawężonym zakresem wolności w dokonaniu wyboru. Porządek prawny nie zajmuje się jednak, zasadniczo, ochroną jednostki przed nią samą. W materii błędu możliwe jest jednak zaskarżenie nieważności zgody małżeńskiej o tyle o ile sam błąd, niezależnie od przyczyn które go wywołały, spowodował nieważność małżeństwa. Przepisy kodeksowe mają w tej materii charakter deklaratywny, mimo pewnej ewolucji tak w regulacji błędu prawnego (obecny kan. 1099 uzupełnia kan. 1084 KPK 1917) jak i błędu faktycznego (por. nową regulację dokonaną w kan. 1097). Cała ta problematyka pozostaje jednak poza zakresem przyjętego w tytule tematu, ze względu na to, że racją dyspozycji legislacyjnych w materii ignorancji (kan. 1096) i błędu (kann. 126, 1097 i 1099) nie jest bezpośrednio ochrona wolności nupturienta w zawieraniu małżeństwa, lecz raczej deklaracja norm regulujących w tej materii ważność samej zgody (z prawa naturalnego czy ex natura rei) i zagwarantowanie pewności prawnej, niezbędnej dla ewentualnego późniejszego dochodzenia uprawnień związanych z nieważnie zawartym małżeństwem. 
W tym momencie warto zatrzymać się jeszcze nad pewnym aspektem szczegółowym wspomnianych wyżej form błędu faktycznego. Regulacja prawna, dokonana w kann. 126 i 1097, abstrahuje całkowicie od przyczyny błędu. Nie ma znaczenia czy błąd co do osoby lub błąd istotny co do przymiotu osoby wystąpił spontanicznie względnie na skutek celowego działania innych osób. Zasadniczy skutek prawny takiego błędu (nieważność zgody) jest związany z samym błędem substancjalnym a nie z jego przyczyną. W tym właśnie kontekście na kilka lat przed rozpoczęciem Soboru Watykańskiego II pojawiła się petycja o ustanowienie ochrony prawnej w sytuacjach kwalifikowanego błędu akcydentalnego, spowodowanego mianowicie przez podstęp ze strony innej osoby ${ }^{27}$. Błąd substancjalny, wywołany przez podstęp, nie wymagał dodatkowej ochrony prawnej, jako że była ona przewidziana od dawna, co więcej istniała ex natura rei: tradycyjnie nie było wątpliwości co do możliwości stwierdzenia nieważności małżeństwa jeśli nieważność wynikała z prawa naturalnego, mimo iż dana forma nieważności nie była zadeklarowana na płaszczyźnie legislacyjnej. Natomiast przed wejściem w życie Kodeksu z 1983 r. nie istniała ochrona prawna przez błędem akcydentalnym co do przymiotu osoby kontrahenta, nawet jeśli tego rodzaju błąd został wywołany przez podstęp.

Komisja ds. rewizji Kodeksu poświęciła sporo uwagi, by ochrona prawna przed podstępnym wprowadzeniem w błąd $\mathrm{z}$ jednej strony była do dyspozycji w przypadkach, które na to rzeczywiście zasługują, a z drugiej strony nie była zbyt szeroka, narażając na nieważność sporą ilość małżeństw. Owocem tych wysiłków jest dzisiejszy kan. 1098, w myśl którego nieważne jest małżeństwo zawarte pod wpływem podstępu, dokonanego dla uzyskania zgody małżeńskiej, dotyczącego takiego przymiotu drugiej strony, który ze swej natury może poważnie zakłócić wspólnotę życia małżeńskiego. ${ }^{28}$

$\mathrm{Na}$ płaszczyźnie doktrynalnej i jurysprudencyjnej ${ }^{29}$ wysunięto różne możliwe racje prawne kan. 1098. Obecnie przyjmuje się bez

${ }^{27}$ Zob. H. F 1 a t t e n, Quomodo matrimonium contrahentes iure canonico contra dolum tutandi sunt, Colonia 1961.

${ }^{28}$ Por. cenną monografię W. G ó r a 1 s k i - G. D z i e r ż o n, Nieważność matżeństwa zawartego pod wptywem podstęu, Warszawa 2004.

${ }^{29}$ Por. np. M.T. R o m a n o, La rilevanza invalidante del dolo sul consenso matrimoniale (can. 1098 C.I.C.): dottrina e giurisprudenza, Tesi Gregoriana - Serie Diritto Canonico - 44, Roma 2002, s. 95-168. 
trudności, że zasadniczą racją, ustanowionej w kan. 1098, ochrony prawnej przed podstępnym wprowadzeniem w błąd w zawieraniu małżeństwa, jest ochrona wolności w procesie formacyjnym decyzji zawarcia małżeństwa: podstępne wprowadzenie w błąd co do przymiotu drugiej strony, istotnego dla wspólnoty życia małżeńskiego, ogranicza możliwość wyboru ze strony woli z powodu wypaczonego obrazu współmałżonka. A więc ma tu miejsce ograniczenie wolności woli, mimo iż skutkujące tylko pośrednio przez funkcję poznawczo-intelektualną. ${ }^{30}$

Gdy idzie o zakres ochrony prawnej udzielonej w kan. 1098, istotna jest odpowiedź na pytanie o pochodzenie tej sankcji prawnej i możliwość, lub nie, aplikacji retroaktywnej kan. 1098. Na płaszczyźnie doktrynalnej brak jednoznacznej odpowiedzi. Natomiast orzecznictwo rotalne ${ }^{31}$, początkowo wyraźnie podzielone, zdaje się podzielać coraz wyraźniej zdanie, że przedmiotem regulacji normatywnej ustanowionej w kan. 1098 są jedynie te formy akcydentalne błędu, które zostały wywołane przez kwalifikowany w tym kanonie podstęp. A więc należałoby przyjąć, że sankcja nieważności zgody wyrażonej na skutek takiego podstępu obowiązuje jedynie na mocy woli Ustawodawcy, mimo iż jest postulowana przez różnorakie racje, sięgajace korzeniami do prawa naturalnego ${ }^{32}$. Same te racje nie powodują jednak nieważności, dlatego mowa tu o błędzie akcydentalnym. Teoretycznie nie można wprawdzie wykluczyć, że w szczególnym przypadku podstępne wprowadzenie w błąd mogłoby skutkować błędem substancjalnym (najbardziej wyraźnym przypadkiem byłby błąd co do osoby), wówczas jednak sam błąd substancjalny byłby przyczyną nieważności i na płaszczyźnie procesowej należałoby zawiązać spór z tego tytułu, a nie z tytułu podstępnego wprowadzenia w błąd (kan. 1098). ${ }^{33}$ Przyjęcie takiego ro-

${ }^{30}$ Inne ważniejsze racje, które były wysuwane, to: słuszność kanoniczna, zaradzenie niesprawiedliwości, sankcja karna wobec sprawcy podstępu i ochrona sakramentalnej godności małżeństwa.

${ }^{31}$ Zob. M.T. R o m a n o, Il dolo (can. 1098), w: AA.Vv., La giurisprudenza della Rota Romana sul consenso matrimoniale (1908-2008), Studi giuridici - 83, Città del Vaticano 2009, s. 85-104.

${ }^{32}$ Por. L. G h i s o n i, La questione della retroattività o meno del can. 1098 secondo la giurisprudenza rotale, w: „Quaderni dello Studio Rotale” 15 (2005), s. 123-150.

${ }^{33}$ Zamieszanie w tej materii zostało wywołane głównie przez mało precyzyjne odpowiedzi udzielone dnia 8 lutego 1986 i 12 grudnia 1986 przez kard. Rosalio J. Castillo Lara, Przewodniczącego Pap. Komisji ds. interpretacji autentycznej Kodeksu Prawa 
zumowania pociąga za sobą konkluzję, że kan. 1098 nie ma mocy retroaktywnej i ponadto nie znajduje zastosowania do małżeństw zawartych poza porządkiem prawnym Kościoła katolickiego. Ostatni aspekt jest ogromnie istotny w przypadku rozpatrywania przez trybunały Kościoła katolickiego spraw o nieważność małżeństw akatolików ${ }^{34}$.

\section{Zakończenie}

Ten pobieżny zarys ochrony wolności nupturientów w kanonicznym porządku prawnym, ograniczony z konieczności do niektórych kwestii, ukazuje siła rzeczy jej wieloaspektowy charakter. Oczywista jest wartość małżeństwa i jego głęboko teologiczno-ludzkie konotacje. Stąd jawi się konieczność proporcjonalnej wolności w podjęciu tak istotnego kroku. Wolność nupturientów jest postulowana nie tylko przez godność osoby ludzkiej kontrahentów, ale jawi się jako niezbędna przesłanka dla ich autodeterminacji w zawarciu małżeństwa. Dodatkową racją zainteresowania Kościoła w ochronie tej podstawowej wartości jest wymiar sakramentalny małżeństwa.

Oprócz fundamentalnego uznania w kanonicznym porządku prawnym prawa do zawarcia związku małżeńskiego i wolności od jakiegokolwiek przymusu w wyborze tego stanu życia, przewidziana jest również ochrona pośrednia, pozwalająca na stwierdzenie nieważności zgody w przypadku ciężkiego przymusu, o ile skutkuje poważną bojaźnią, od której kontrahent nie może się uwolnić inaczej jak przez zawarcie małżeństwa (kan. 1103). Podobny skutek pociąga za sobą poważny brak wolności wewnętrznej, jeśli uniezdalnia osobę do zawarcia małżeństwa (kan. 1095). Ponadto Ustawodawca udziela ochrony prawnej przed podstępnym wprowadzeniem w błąd, zawężającym pośrednio wolność wyboru (kan. 1098). Pewną trudność stanowi ustalenie dokładnych granic tej ochrony prawnej, która ma na uwadze jedynie istotny wymiar wolności, co powoduje

Kanonicznego (pełny tekst tak interpelacji jak i wzmiankowanych tu odpowiedzi podaje C. G. F ü r s t, La natura del dolo nel diritto matrimoniale canonico e il problema della retroattività del can. 1098, w: Diritto matrimoniale canonico, vol. II: Il consenso, Studi giuridici - 61, P. A. Bonnet - C. Gullo [red.], vol. II, Città del Vaticano 2003, s. 204-207). W sensie krytycznym por. coram Erlebach, wyrok z dnia 31 stycznia 2002, w: „Ius Ecclesiae” 19 (2007), s. 110-111.

${ }^{34}$ Por. Instr. Dignitas connubii, art. $3, \S 2$. 
że akcydentalne naruszenie wolności nupturientów, mimo iż zawsze naganne, nie powoduje nieważności ich zgody małżeńskiej.

\section{Protezione della libertà dei nubendi nell'ordinamento canonico. Abbozzo della problematica}

In primo luogo viene preso in considerazione il principio della libertà dei nubendi. L'Autore prende lo spunto dal can. 219, ma prima di affrontare gli aspetti propriamente giuridici, si sofferma su alcuni elementi dell'accezione antropologica e teologica della libertà nel contesto del consenso matrimoniale. Lultimo aspetto permette di superare una visione meramente soggettivistica, per quanto riguarda i nubendi, e, d'altro canto, offre una chiave di lettura dello sforzo effettuato lungo i secoli da parte del Magistero della Chiesa nella difesa e nella regolamentazione dello ius connubii. Ne segue la pastorale ordinaria volta all'educazione per un retto esercizio della libertà positivamente intesa dei contraenti. Tornando sugli aspetti prettamente giuridici del principio affermato nel can. 219, l'Autore fa presente la differenza fra i confini del contenuto normativo (volto contro le varie forme di costrizione) e una più ampia ratio legis (protezione della libertà).

Passando alla protezione giuridica della libertà, l'Autore esamina le principali figure di nullità del consenso, dovute alla limitazione della libertà in uno dei contraenti: costrizione, mancanza della libertà interna e raggiro.

Nella materia della costrizione l'Autore distingue nettamente le figure della violenza (di cui nel can. 125, § 1) e della vis vel metus di cui nel can. 1103 (cf. can. 125, § 2). Maggiore attenzione è stata posta all'evoluzione della disciplina dal Codice Pio-Benedettino e alla sua applicazione giurisprudenziale. Un punto discusso costituisce l'origine della norma. L'Autore si sbilancia in favore del principio dell'operatività della norma ex natura rei (cioè della nullità qualora manchi nel concreto la libertà necessaria, matrimonio proportionata), quindi sostiene l'applicabilità del can. 1103 , entro tali limiti, nei confronti dei matrimoni degli acattolici.

La mancanza della libertà interna è presa in considerazione nel contesto dell'incapacità consensuale, in particolare della mancanza della discrezione di giudizio. Viene accennata qui la questione dell'autonomia, o meno, del capo di nullità ob defectum libertatis internae (l'Autore condivide, implicitamente, la dominante posizione giurisprudenziale, contraria a tale autonomia).

Per quanto riguarda la decezione dolosa, la tutela della libertà dei nubendi è considerata come principale ratio del can. 1098. Viene brevemente delineata la specificità di questo tipo di errore qualificato. Soffermandosi sui limiti dell'applicabilità del can. 1098, l'Autore sostiene che seppure la ratio legis del can. 1098 affonda le radici nel diritto naturale, tuttavia la ratio nullitatis è riconducibile 
alla volontà del Legislatore. Di conseguenza, il can. 1098 è da ritenere di diritto meramente positivo e, in quanto tale, non è applicabile retroattivamente, né può essere fatto valere nel caso dei matrimoni celebrati al di fuori dell'ordinamento giuridico canonico indipendentemente dalla loro data. Invece nel caso di un errore sostanziale causato dal dolo, la nullità è operante indipendentemente dalla decezione dolosa, quindi andrebbe rilevata a livello processuale sotto il capo di quel particolare errore sostanziale.

La promozione della libertà responsabile avviene soprattutto sullo sfondo dell'accezione teologica della libertà con la quale si coniuga l'accezione antropologica, soprattutto quella della "libertà per" che postula l'autodeterminazione nel consenso matrimoniale. Lincapacità o l'impossibilità di una tale autodeterminazione viene riconosciuta dal Legislatore proteggendo indirettamente la libertà consensuale nei cann. 1095, n. 2, e 1103; mentre la libertà dei nubendi è ulteriormente protetta contro il raggiro nei limiti stabiliti nel can. 1098. 